Trinity College

Trinity College Digital Repository

Faculty Scholarship

$3-2008$

Research for Change versus Research as Change: Lessons from a Mujerista Participatory Research Team

Andrea Dyrness

Trinity College, andrea.dyrness@trincoll.edu

Follow this and additional works at: https://digitalrepository.trincoll.edu/facpub

Part of the Anthropology Commons, and the Education Commons 


\title{
Research for Change versus Research as Change: Lessons from a Mujerista Participatory Research Team
}

\author{
ANDREA DYRnESS \\ Trinity College
}

In this article, I aim to further the discussion of engaged research in anthropology and education by examining the unique changes promoted by participatory research in contrast to policy-oriented activist research models. Drawing on my work with Latina immigrant mothers in a school reform movement, I argue for a Latina feminist view of participatory research that illuminates and builds on Latina women's capacities for social critique and transformative resistance. [participatory research, activist anthropology, Latino parents, school reform]

We can no longer afford to live with the comforting illusion that we act upon the world in socially just ways simply by inscribing and cataloguing the many cases in which justice is absent.

-Catherine Emihovich, Council on Anthropology and Education 2004 Presidential Address ${ }^{1}$

We're here because we want something better for our children, and for our community.

-Madres Unidas ${ }^{2}$

In recent years, there has been a call for anthropologists of education to lend their work to progressive public policy goals (Foley and Valenzuela 2005; González 2005; Nygreen 2006; Weis and Fine 2000). In an era of public and corporate assault on public education - in the form of heightened standardization, regulation, and surveillance of public schools, and growing calls for privatization-it is with growing urgency that progressive scholars seek to support the efforts of underserved communities to achieve greater justice and equity in the educational system. It has become increasingly recognized that engaged research-research that explicitly aims to support social change efforts-is possible, theoretically defensible, and ethically necessary (Hale 2006; Hernández-Castillo 2006; Lipman 2005; Nygreen 2006; Scheper-Hughes 1995; Speed 2006). However, writings about activist anthropology have seldom distinguished between the kinds of changes that different models of engaged research promote, or examined the implications of different social change strategies for the researcher and research participants. In my reading of the activist research literature, there is a distinct privileging of activist research that seeks changes in the legal realm (new public policies, or new rights and resources for underprivileged groups) at the expense of exploring other kinds of changes that research might promote. In this policy-oriented activist research model, researchers lend their research products and expertise to the service of marginalized groups seeking specific, winnable policy changes.

In contrast to this, however, is a research process that aims to transform relationships between "researcher" and "subjects" and expand the capacity of participants to

Anthropology \& Education Quarterly, Vol. 39, Issue 1, pp.23-44, ISSN 0161-7761, online ISSN 1548-1492. (C) 2008 by the American Anthropological Association. All rights reserved.

DOI:10.1111/j.1548-1492.2008.00003.x. 
make change in their own communities. This model, which has become known as participatory research, involves community members typically seen as research subjects as coinvestigators in a collective process of inquiry, reflection, and action (Fals-Borda and Rahman 1991; Maguire 1987; Park 1993). Unlike models of engaged research in which researchers advocate for change on behalf of community groupsthrough lobbying, writing, or testifying in the public arena-in participatory research, the community members themselves are agents of change. Granting new agency to uncredentialed and unelected community members, and bypassing official channels for making change in communities, participatory research runs the risk of conflicting with many powerful institutional players, such as university researchers, policy makers, reformers, and community organizers, who have traditionally maintained the right to lobby for change. Understanding these conflicts and the politics they reflect offers activist researchers new theoretical insights, as well as new possibilities for supporting social change processes.

Drawing on my own work with Latina immigrant mothers in a school reform movement, I examine some of the unique changes promoted by participatory research, and the ways they may conflict with other social change strategies: particularly, in this case, community organizing for education policy reform. While I hoped to lend my research to the goals of a larger community organizing movement, collaboration with the mothers in Madres Unidas (Mothers United), our participatory research team, sometimes brought us into conflict with movement organizers. In this article, I draw on critical feminist perspectives to illuminate the mothers' critique of the larger organizing movement, and the ways the mothers, through our research, created an alternative space that promoted personal transformation and enhanced their own capacity to make change in their lives. A race-based feminist, or mujerista, perspective (Villenas 2001, 2005) reveals the multiple relations of domination and inequality at work in the community organizing movement, and the ways these were experienced and resisted by a group of low-income, Spanish-speaking, noncitizen, Latina immigrant mothers.

In this article, I thus tell two parallel stories, using each to illuminate the other: the story of Madres Unidas and their work for change in their children's new small school, and the story of our research methods as they unfolded and provoked particularly strong reactions from movement leaders. These stories provide complementary theoretical insights into the politics of social change movements and activist research methods. I argue that participatory research from a critical, Latina feminist lens expands our vision of the kinds of changes research can support, drawing on the agency and cultural resources of local actors and their own strategies for making change. In doing so, it disrupts essentializing views of social change movements and activist research methods that leave change in the hands of specially trained "experts."

Before describing my research, I will briefly review some relevant literature in activist research and Chicana/Latina feminist epistemologies to illuminate the sources of my critique. I will then describe the research context, the movement for new small schools where Madres Unidas work took place, and my entry into the research. In the remainder of the article, I analyze three kinds of changes that Madres Unidas facilitated for the participating mothers and the ways these changes were received at the school. Throughout this discussion, I interweave data on the Madres' collective research with the reactions of professional school reformers and organizers to our research and actions at the school to highlight the sources of tension and 
conflict, as well as the moments of hope and synergy, between our research and the movement for new small schools.

\section{Activist Research and Latina Feminist Epistemologies}

While a complete genealogy of activist research in anthropology and education is beyond the scope of this article, a number of recent studies together reveal the policy-oriented bent of activist research, which I contrast to participatory research processes. ${ }^{3}$ My intent is not to discount the importance of activist research for public policy, but to highlight what is lost in a body of literature that too narrowly limits the scope of activist research to public policy change. I introduce Latina feminist perspectives as a way to re-center on the research process as an important venue for making change in everyday life.

Douglas Foley and Angela Valenzuela (2005), in their review of various models of collaborative research, distinguish between scholars who write cultural critiques, who do applied policy studies, and who involve themselves directly in political and social movements. Describing a continuum of activist research from least to most direct involvement in political action, they offer their own work as case studies representing opposite ends of the continuum. On one end, Foley writes cultural critiques and attempts to make them more collaborative, accessible, and politically useful by involving community members in their editing and revising, among other things. Foley focuses his innovation on textual strategies that affect the final research product while not significantly redefining the research process. At the other end of the continuum, Angela Valenzuela became directly involved in the legislative process in Texas in an attempt to influence educational policy for Latino students. Drawing on her own expertise and research on Latino students, she helped author a bill for a more just assessment approach, based on multiple measures of academic performance, as an alternative to the state's standardized test. In this case, community members were not involved in shaping the research process or product, but Valenzuela worked to defend their interests in the legislative realm.

Foley and Valenzuela assert that "the most politically active form of action anthropology emphasizes direct involvement in political movements, court cases, and aggressive organizing activities," of which Valenzuela's work is a prime example (2005:224). However, even in this model of activist research, it is the researcher's knowledge production that is key to the change process, not that of community members. This continuum of activist research, even at its most politically active end, maintains a separation of roles between expert researcher and community members who must rely on this (others') expertise in their struggles for change. The underlying assumption that research is separate from action for change prevents us from seeing other possibilities in activist research: how community members also produce knowledge that is useful in struggles for change, and how the research process itself could be an important possible arena for making change.

While I affirm the vitally important role of activist anthropology for public policy, a characterization of activist research that presumes these are the only possibilities for collaboration, or that public policy is the only way to enact social change, ignores the multifarious ways that inequality is reproduced and contested in everyday life. I am troubled by the growing perception among activist researchers that to effect social change, researchers must tailor their research products to powerful governing bodies 
(legislatures, school boards, or courts; see González 2005; Hale 2006; Lipman 2005; Nygreen 2006). In some cases, this involves an outright sacrifice of critical, reflexive, or collaborative research methods, in order to produce more credible and "authoritative" accounts of social realities.

Charles Hale (2006) described this contradiction most forcefully in his account of activist research for indigenous land rights in Nicaragua. He argues that disenfranchised communities who are seeking new rights from the state will have little tolerance for cultural critiques produced by well-meaning ethnographers. They need, instead, an objective and infallible social science to advance their interests in the public sphere. Accordingly, he suggests that activist researchers more willingly embrace positivist research methodologies in the service of marginalized groups, even as they subject these methods to critique. In Hale's research, research products including computer-generated, georeferenced maps representing the territories indigenous communities claimed as their own, ethnographies showing the basis for these claims, and expert testimony in the Inter-American Human Rights Court were the key tools in the struggle for indigenous land rights. Similarly, Pauline Lipman (2005) and her university colleagues produced maps showing the intersection of gentrification patterns and school closings in Chicago to aid African American community organizations in their efforts to fight school closings in their neighborhoods.

These scholars reflect the important social change battles being waged in the legal realm to defend the rights of minority groups across the Americas. They also reflect a conception of the role of the researcher as a mediator or broker between disadvantaged community groups and legal bodies such as legislatures, school boards, and human rights courts. In these cases, the possibilities for change come not from how research is conducted but how it is used, and knowledge production remains firmly in the hands of the expert researcher. As Hale says, anthropologists allied with people in struggle must "generate the kinds of knowledge they ask and need us to produce" (2006:115, emphasis added).

Other scholars have critiqued the focus on legalism by activist scholars such as these (see Brown 1995; Brown and Halley 2002; Speed 2006). In focusing on shortterm legal goals, these scholars point out, activist researchers may neglect to examine the ways their own scholarly production might reinforce structures and discourses of domination. Another concern, raised by feminist political theorist Wendy Brown (1995) is that, in seeking redress for "injury" from the state, leftist activists reinforce the power of the state over all other realms of social relations where inequality is reproduced. If we believe that only the state has the power to make necessary changes (through the distribution of rights and resources), we neglect the way power operates in everyday life, and we do nothing to expand the capacity of ordinary citizens to confront relations of power and domination in their own lives. These critiques of leftist activism lay the groundwork for a rationale for a critical Latina feminist approach to participatory research.

Participatory research, which strives to erase the distinction between "expert" researcher and research subjects and democratize the process of knowledge production, is not new (Fals-Borda and Rahman 1991; Hernández-Castillo 2006). But it is curiously absent from recent writings on activist research in anthropology, perhaps because, as one anthropologist put it, its practitioners often "uncritically endorse and celebrate popular knowledge" (Hale 2006:108). Looking to the work of LatinaChicana feminist scholars, however, offers a theoretical understanding of the role of 
popular (nonexpert) knowledge in social change struggles. Bridging participatory research methods with Latina feminist epistemologies allows us to break open the tired dichotomies between researcher and community members, and between critical analysis or theory and action for social change.

A Latina feminist framework, like other race-based feminisms (Collins 2000; hooks $1989,1990)$, provides a way of understanding the intersection of racism, sexism, and classism and how this affects the everyday lives of Latina women (Delgado Bernal 2006; Villenas 2001). ${ }^{4}$ The focus on everyday life is key, because it is here where oppression and inequality are experienced and resisted daily. Chicana/Latina feminist scholars have broken ground in highlighting the "everyday resistance strategies of Chicanas/Mexicanas that are often less visible, less organized, and less recognizable" (Delgado Bernal 2006:116). A growing body of work by Chicana feminist scholars has shown that Latina women are already involved in making change in everyday life by nurturing resistance to oppression at home with their children, that is, using the home and familial cultural practices to resist oppressive structures outside the home (Delgado Bernal 2006; Villenas 2001). This work has been essential for theorizing the agency and cultural resources of Latina women in Latina-controlled community spaces. Within the context of larger political movements for change, a Latina feminist perspective asks, how do Latina women experience and live the social movement, and how is their agency expanded or constrained? A Latina feminist, or mujerista, lens calls attention to the means of achieving change, and highlights the need for a research process that supports womanist ways of being in community, based on wholeness and confianza (trust). Wholeness, in Latina feminist thought, acknowledges the need for personal healing and for the emotional, spiritual, and relational resources that Latina women draw on in their struggles against oppression (Trinidad Galván 2006). As Ruth Trinidad Galván explains, "A mujerista vision enlightens our understanding of pedagogies that encompass personal, collective, spiritual, and survival undertakings" (2006:175).

I suggest that participatory research offers a way to better understand, build on, and extend the resistance strategies of Latinas in the home to public spaces such as schools while also offering a unique space for Latinas to critique their position within social movements. Below, I will draw on my own work to illuminate what I mean by participatory research from a critical Latina feminist lens. The following discussion is based on over three years of ethnographic fieldwork, including a year-long participatory research project with Madres Unidas, conducted from 2000-03. Data sources include my own field notes, transcripts of interviews and informal discussions I had with members of Madres Unidas, transcripts of interviews and focus groups with parents and teachers conducted by the Madres in my presence, and the mothers' written reflections on their research. The analysis of the data for the participatory research project was conducted collectively by the mothers, as they prepared for three public presentations of their research: at two professional conferences and to the staff of their children's school. The analysis of our group process is my own (drawing extensively on the mothers' written and oral reflections on our group).

\section{The Research Context: Organizing for New Small Schools}

The context of my research was a citywide community organizing movement in Oakland, California, aimed at reversing inequities in the Oakland public schools 
through the creation of new small autonomous schools. The small schools movement was widely dubbed a "community-based movement," because it originated with parents organized by Oakland Coalition for Community Action (OCCA, a pseudonym), a grassroots, faith-based membership organization with a long history of organizing the neediest communities in Oakland. The small schools movement aimed to include parents and community members as partners in the design and creation of the new small schools. It began when parents in Oakland's "flatlands"-low-income, densely populated neighborhoods made up of African Americans and Latino and Asian immigrants-began protesting the deplorable conditions in their children's schools, which were among the most overcrowded and underperforming schools in the city and the state.

Latino parents in OCCA played leadership roles in mobilizing the community for public "actions" and testifying before public officials at these actions, events that were critical for bringing the reform to the public's attention and getting the New Small Autonomous Schools policy passed in May 2000. But while parents played key roles in bringing the new schools into being by exerting political pressure on the district, their participation in the design of the new schools was much more contested. The questions that came to guide my research were: What does it mean to involve "the community" in school reform? How were "community" and "participation" constructed by organizers, teachers, and parents in the reform?

The small schools movement involved three distinct sets of actors: professional school reformers and community organizers from two community organizations who spearheaded the movement; school staff who helped design and later taught in the new small schools; and parents who lived in the community and sent their children to the new small schools. Although some parents were members of OCCA, the relevant distinction for the purposes of this article was between paid professionals who were loyal to an organizational mission and identity (including reformers, organizers, and teachers), and parents and other community members who gave their time to the movement out of concern for their own children and their community. These two groups differed markedly along lines of class, language, immigrant status, residential location, prestige, and access to information and resources.

I began my research as a doctoral student hoping to conduct an ethnography of the movement that would be both useful to movement organizers and acceptable to my dissertation committee. I strongly believed in the importance of the small schools reform as a movement for equity and social justice, as it was framed by movement organizers, and I wanted to lend my research to their goals. To that end, I approached the leadership of OCCA and a partnering school reform organization to gain permission for my research and seek their input into its direction. OCCA staff directed me to meet and build rapport with parent leaders first before attempting any formal research. So, at their suggestion, I began attending local organizing committee meetings in the neighborhood that became the focus of my research. I joined the "design team" of parents and teachers who were planning a new small school, and I offered my services as a translator and interpreter. Nearly all of the parents at these meetings were Spanish-speaking Latino immigrants, and although some of the teachers and the OCCA organizers spoke Spanish, interpretation was spotty and haphazard. I began translating and interpreting informally for a group of parents and soon was asked to translate formal documents for both teachers and parents. 
It was through my role as a translator that I gained "access" and, eventually, earned the trust of parents and teachers on the design team. My own racial and cultural identity placed me in a unique position with respect to the teachers, who were 90 percent white (all but two) and the parents, who were predominantly Spanishspeaking immigrants from Central America and Mexico. I am both racially white, middle-class, and a bilingual, bicultural Central American Latina. As such, I had multiple poles of commonality and difference with both teachers and parents. As a graduate student ethnographer from a prestigious school of education, I had access to meetings and information about the reform that parents did not always have access to. It was in this capacity of "translation," not just from English to Spanish and vice versa but, rather, from the world of education research and reform to the world of Latino immigrant parents, that I first felt the need for a participatory research project that would involve Latino parents as partners in research. In conversations with Baudelia, a parent leader who had organized early Design Team meetings, I began to learn of subtle ways that parents were being excluded from the process of planning the new small schools. Baudelia's frustration at having been excluded, in spite of the many hours she had spent organizing parents, began to suggest the direction my research should take if it hoped to promote change.

\section{From Frustration to Resistance: Madres Unidas}

Through my first year of ethnographic research on the small schools movement, as I observed anxious teachers struggling with how to include parents in their plans for reform, and frustrated parents struggling to be recognized, I thought of the question W. E. B. Du Bois once asked of African Americans: "How does it feel to be a 'problem'? " Like Latinos in the South described by Sofia Villenas (2001) and Enrique Murillo (2002), Latino parents were a "problem" for education reformers in the small schools movement. They were a problem for reformers' work, needing to somehow be involved, and they were victims of educational inequality and injustice that the reformers hoped to change. But they were often not present at the table when decisions about reform were being made.

African American feminist scholar bell hooks (1989) writes of being excluded from the feminist movement by white women who claimed to be antiracist. White, liberal women requested and longed for the presence of black women yet "wished to exercise control over our bodies and thoughts as their racist ancestors had" (1989:112). Liberal whites, she argues, have become so used to speaking for the "Other" that they are not aware of how their speech silences those who most need to be heard. hooks calls our attention to the deep paternalism underlying many progressive change efforts initiated by whites, where people of color are spoken about, rather than invited to speak as experts of their own experience. "Often this speech about the 'Other' annihilates, erases: 'No need to hear your voice when I can talk about you better than you can speak about yourself' " (1990:152). This was certainly true in the countless incidents I observed of parent voices and concerns being excluded, forgotten, glossed over, or ignored by progressive educators who aimed to serve them.

At the end of my first year of research, I faced a choice. I had well-developed relationships with a group of Latina mothers who were indignant at the way reform was proceeding at their children's school. I could continue to document their pain and frustration and hope that my written product would fall on sympathetic ears, or 
I could facilitate the mothers' own inquiry and action to address the problems that mattered to them. The factors that influenced my decision to initiate a participatory research project were the support in my graduate program for alternative epistemologies and activist research methodologies and my assessment of what would be most useful to the parents at my research site. Given the fact that much of the parents' frustration stemmed from the failure of school professionals to recognize their ability to discuss serious educational issues, the choice to involve parents as researchers seemed obvious. Interestingly, and perhaps to my detriment, a factor that I did not take into consideration was how movement organizers from OCCA and partnering organizations would respond to my research. Because I believed I was conducting research that was supportive of their goals of increasing community participation in the reform, I naively assumed that they would welcome my research. But I could not have anticipated the kinds of changes a participatory research project would bring, or the responses these changes would generate.

Madres Unidas began meeting a week before the new small school opened. ${ }^{5}$ The group consisted of five immigrant mothers: two from Mexico, two from El Salvador, and one from Guatemala. All but one of them had been active on the design team for United Community School (UCS, a pseudonym) and had children in the new small school. Ofelia, an energetic and outspoken young mother from El Salvador, offered her home as a meeting place. For the next year we met weekly and sometimes twice weekly in her home. We planned and carried out focus groups with parents, teachers, and students, and individual interviews with the principal, parents, and OCCA organizers. Through a grant I obtained, we were able to buy a video camera and hire a video instructor who taught the mothers how to use the video camera. We recorded most of our research activities and watched videos together as a means of evaluating our performance and analyzing what we learned. We also recorded several of our own meetings.

Participatory research, in the words of Patricia Maguire, is "a process of collective, community-based investigation, education, and action for structural and personal transformation" (1993:157). Although the process is often instigated by an outside researcher, ideally, the research question or problem is defined by the community. In Madres Unidas, the research problem we collectively chose to explore grew out of the year we had spent together on the design team before the participatory research began. Most broadly, the problem addressed the role(s) that parents were playing in the new small school and the ways these roles were being defined (and limited) by school staff. We wanted to start by examining the history of school and recording the experiences of parents and others who had participated in its development. Another goal was simply to understand how the reform was working at UCS. If UCS was a story of reform, what exactly was this reform and how was it being put into practice? This was the question most compelling to the mothers, who, as parents who had participated in planning the school, were desperate to understand their experience and figure out how closely the school was adhering to its vision. As it turned out, this was the objective that would get us into trouble with the organizers and school staff, as it would inevitably illuminate aspects of the school and the reform that were not working. From the perspective of the mothers and the theoretical underpinnings of participatory research, this function of the research was the most important, as it would empower them to take action for change (Maguire 1987; Park 1993). 
In the remainder of the article, I argue that Madres Unidas facilitated three kinds of changes for the five participating mothers: it enabled them to develop a critical analysis of school practices, policies, and power relations that silenced them and other parents; it provided a safe space for the creation of community based on confianza (trust) and the use of testimonio (testimonial); and it allowed the mothers to take on new roles at the school and extend their vision of community from Ofelia's house to the larger school community. All three of these changes, which were overlapping and mutually constituted, are illustrative of core features of participatory research and critical feminist and mujerista epistemologies. However, in expressing a critique of power relations in the reform and the larger movement, these changes also provoked sharp resistance from movement organizers, reformers, and school staff.

\section{Critiquing the Politics of Exclusion}

To be sure, the mothers in Madres Unidas did not need to conduct research to develop a critique of the role of parents in the reform: they had a rich critique already from their own experience. What Madres Unidas provided was the opportunity to deepen and extend this critique by providing a venue for being together in which they could collectively explore their experiences, inquire into the experiences of other parents, and analyze these experiences together in light of broader patterns at the school. At the beginning of the year, there were disturbing signs that the patterns of exclusion that had shaped the planning process were present in the new small school. Decisions voted on by parents were overturned by the principal; votes cast for parent representatives on the School Site Council (SSC) were disregarded; promises made by the staff in their proposal were broken, seemingly forgotten. In our early research meetings, the mothers wondered: How was it possible for school staff and organizers to continue to urge parents to come out to meetings when they seemingly had no intention of listening to or considering parents' voices?

As one mother put it, teachers called parents "when they just need bodies." The mothers pointed out how many times they had been asked to crowd school board meetings and OCCA actions, when the bodies of parents had been critical to win concessions from city officials. Within the school, the mothers discussed how parents were invited "to organize things for parties," but never to plan an academic program. The pattern was for teachers to encourage parent participation "when it benefits them [teachers]." The invitation to participate in body but not in mind-to be present in the audience at an Action or School Board meeting, to serve on the SSC, to vote on a policy at a parent meeting, while their actual opinions and concerns were silenced-felt distinctly manipulative to the mothers. "Están logrando sus objetivos, no los objetivos de los padres," [(The teachers) are achieving their own objectives, not the parents' objectives] Baudelia observed. Through interviews and focus groups with other parents in the school, the mothers uncovered other experiences of exclusion, leading Ofelia to write in a reflection, "Los padres se sienten utilizados" [Parents feel used].

The mothers also identified how school staff silenced parent critique by publicly framing outspoken parents as "bad parents." The mothers perceived that they had been branded as antagonists or troublemakers by the principal and several staff for speaking up to question teachers' decisions or calling out exclusionary practices. This view of the mothers was most shockingly revealed when the parent governance committee was announced. Baudelia, as the parent who had received the most votes, 
was to be the council president. However, when the principal announced the results at a general parent meeting, she warned that if Baudelia wanted to serve on the committee, she would have to "change her attitude." This was one of several ways the staff enforced the "good parent-bad parent" binary to delegitimize the claims of "problem parents." The "good parent," the mothers knew, was the parent who said and did exactly as the principal or teachers wanted. Like a "puppet" (marioneta) or a "parrot," in the words of Madres Unidas, the "good parent" was expected to be a mouthpiece for the staff, with no opinions or agency of her own. In contrast, those who questioned teachers were told that they had "bad intentions" or "poor group skills." As Baudelia explained it, "Because we are always expressing frankly what we don't like, and we have the courage to say it, and not everyone has the courage. So now it's like whatever we ask for or express, they ignore us. But I think we have the right to keep expressing what we feel."

The censorship of anger as a means of excluding and controlling ethnic minority parents has been documented by other researchers (see, e.g., Crozier 2001; Lareau and Horvat 1999). The "angry parent" has never been welcome in public schools. However, in the context of the small schools movement, it was "angry parents" who had pushed the school board to pass the new small schools policy and forced officials to provide adequate facilities for the new schools. Parents' anger was recognized, welcomed, and even encouraged by OCCA organizers and reform leaders who sought crowds of parents at actions to leverage policy change. However, acceptable anger was so far directed at district and city officials, not at teachers and principals within the new small schools. Once it became clear that Madres Unidas was expressing anger at school staff-seeking to hold them accountable for their promises and plans-organizers and reform leaders became troubled.

It was here that Madres Unidas as a participatory research group encountered its most serious opposition from community organizers and reformers in the small schools movement. As the mothers deepened their critique of exclusionary politics at the school and gained evidence from their research to support this, they were emboldened to confront school staff-both publicly and privately-on issues of conflict and concern. OCCA organizers and other reform leaders working with the school saw this as threatening the success of the reform and began to warn me to put a stop to it. On two occasions, OCCA organizers showed up at our research meetings and began to challenge our research process and findings. They reiterated the principal and teachers' contention that Madres Unidas was only out to find the "negative." In a private meeting with me, one OCCA organizer told me that the Madres were "too angry" in parent meetings and were alienating other parents. It was certainly true that there were some parents who disapproved of the mothers' outspoken habits. But why was the Madres' behavior singled out as problematic, and not that of the parents who preferred to be silent? In highlighting the quiet parents as the desirable norm and isolating the Madres as troublesome, OCCA organizers supported the principal and the reigning power relations at the school.

Other reform leaders, too, warned me of the dangers of naming conflicts at this stage in the reform's history. UCS had two "school coaches" from a school reform organization working, along with OCCA organizers, to help the school in implementing its vision. On different occasions, they both told me that the new school was too vulnerable to risk addressing conflicts at this point, and that our research should be sewing unity between teachers and parents. They counseled me to be "objective" and 
not to take sides in the battles between staff and parents. The problem was, their "objective" interpretation sounded a lot like the principal's and reinforced the notion that the parents who named the problems were the problems. As Baudelia observed after meeting the coaches for the first time, "I feel that they support the principal."

In marginalizing parents who voiced critique, then, school staff had support from powerful institutional partners who carried the force of the small schools movement. In multiple ways, organizers and reform leaders communicated the message to Madres Unidas that the success of the reform depended on forming a single unified front in which there was no room for conflict or critique. They had come this far by delivering a single message to the public, loud and clear. Inequality was the problem; new small schools were the solution. Now Madres Unidas was pointing out inequality in the new small schools, at a time when the future of the new small schools was uncertain. OCCA still had a lot of work to do to convince the city that these communities deserved sustained attention and resources. A research report highlighting successes in the new small schools would help them achieve this agenda; Madres Unidas' findings would not. But what would be lost by silencing parents' critique in order to achieve greater policy victories? In the following section, I attempt to answer this by exploring the kinds of changes the mothers enacted that were only made possible by the safe space created by Madres Unidas.

\section{Creating Community and Confianza}

Madres Unidas held our weekly meetings at Ofelia's house, around her kitchen table, over food and coffee. Although Ofelia had a comfortable living room, the mothers preferred to meet in the kitchen. The kitchen table setting set a relaxed and intimate tone to our meetings. We all had the sense of being welcomed into Ofelia's home, part of the family. As Baudelia said, "Yo me siento bien a gusto de estar en el grupo, porque siento que somos como una familia, o sea porque siento que todas nos entendemos" [I feel really at home in this group, because I feel like we're a family. I feel that we all understand each other]. Meeting in the home allowed the mothers to be present in their wholeness: as mothers, whose children were playing nearby in the other room, and as friends, who cooked for each other, ate together, and shared stories of their personal experiences. It is in these ways I argue that Madres Unidas created a unique mujerista or Latina womanist space (Trinidad Galván 2006; Villenas 2005), based on the use of testimonio and relationships of confianza, which enhanced their capacity to make change at their children's school. Trinidad Galván explains that "a mujerista or Latina womanist vision ... aims to uncover, share, and validate the diverse knowledge and experiences of Latinas in the United States and abroad. It takes a holistic approach to self that includes spirit and emotion, and recognizes our individual-communal struggles and efforts to name ourselves, record our history, and choose our own destiny" (2006:172). As they explored the history of the new small school, the mothers in Ofelia's kitchen supported each other in naming and recording the experiences that had been suppressed, resisting the efforts of school staff to frame them as "problem parents," and recasting themselves as concerned advocates for their community.

Unlike school meetings that excluded, silenced, and delegitimized the personal experiences of parents (Dyrness 2004, 2007), Madres Unidas created a space that privileged personal experience as the foundation of its being. The beginning of every 
meeting was dedicated to open sharing and socializing over food. The mothers discussed new jobs, child care dilemmas, the high cost of health care, or family news. Several mothers testified that this was what they liked best about the group. As Baudelia said, "era bien bonito porque se había la confianza, compartíamos, conocíamos algo que no solamente conocíamos como una compañera de trabajo, sino que fue algo más, más familiar" [It was really nice because there was trust, we shared, we got to know each other not just as co-workers, but something more familylike]. They emphasized the combination of learning, working, and personal sharing that made the group enjoyable to them. As Carmen said, "Drinking coffee, and relaxing, and at the same time learning and sharing personal things from your home life, your kids, and learning a lot at the same time that you're relaxed."

But, importantly, relationships of trust allowed the mothers to retell experiences they had had at the school and debrief painful and frustrating meetings in the company of supportive friends. In doing so, Madres Unidas drew on the practice of testimonio, which has a long tradition in Latin American activism and has recently been revived by Chicana and Latina feminist scholars (Benmayor 1991; Delgado Bernal et al. 2006; Latina Feminist Group 2001). The Latina Feminist Group describes testimonio as a "crucial means of bearing witness and inscribing into history those lived realities that would otherwise succumb to the alchemy of erasure" (2001:2). They note that historically, testimonio as a form of expression was born out of intense repression or struggle, in which the purpose of the story was less about disclosing a personal life than it was about creating a record of violence on whole communities (2001:13). In this way, testimonio serves both personal and collective goals, and is explicitly connected to struggles for justice and liberation. Through testimonio, the mothers in Madres Unidas reaffirmed each other's experiences of injustice at their children's school and supported each other in acts of resistance.

If testimonio was the medium of sharing stories, confianza, a word that means both trust and confidence, created the conditions that made this possible. Confianza enabled mothers who were newly "coming to speech" (hooks 1989) to share their stories and draw strength from them. In one meeting in Ofelia's kitchen, Maelia described feeling scorned in a parent meeting at the school for raising a question that was critical of a new policy. My field notes describe the incident:

\footnotetext{
Maelia reported that the school has instituted a "complaint box" for parents, and parents are to write their complaints or suggestions on a piece of paper and place them in the box instead of bringing them up at the meeting. The mothers thought this unfair because: (1) it keeps them secret, so parents can't find out about other parents' complaints; and (2) how would they know that teachers were actually reading the complaints? Maelia explained that she had brought up the latter issue in the meeting, and she described a feeling of complete mortification as she raised the question, and all eyes turned to her. I was so proud of her for having spoken up! Another new rule she thought was unfair was that parents are to be limited to one question each at the meetings. ${ }^{6}$
}

This particular example was poignant to me because it so clearly revealed Maelia's budding anger and awareness of the ways parents were being silenced by the school and her own coming to speech. Keeping parents' complaints secret in a "complaint box," and limiting them to one question each at parent meetings, was for the mothers a clear attempt by the staff to silence them. When Maelia attempted to break the silence, questioning teachers in front of parents about the fairness of the process, she 
was made to feel deeply embarrassed. She told us she turned bright red as she felt all the eyes in the room fixed on her. Retelling the event to the Madres around Ofelia's kitchen table, she drew on their support and solidarity to recover the dignity that was denied her at the time. In confianza, her act of speaking up was transformed from an experience of shame to an act of resistance. I believe, as other scholars have suggested, that this transformation in the intimacy of the home enabled more public forms of resistance (Scott 1990; Villenas 2001).

One of the earliest experiences Madres Unidas analyzed was that of Baudelia, who had been elected chair of the SSC and then publicly warned by the principal to "change her attitude." The other mothers, who had been present at the meeting, expressed their outrage at the principal's falta de respeto (lack of respect) toward Baudelia and voiced their support and solidarity with Baudelia. They encouraged Baudelia to serve as chair of the council in spite of her misgivings, because they believed the council needed someone like her. Throughout the year, Baudelia brought her experiences on the SSC to Ofelia's kitchen table, where they became part of the group's testimonio. She shared how the principal failed to inform her of a key meeting with a city council member to which other SSC members were invited, and how the principal had forced her to sign a blank form authorizing the budget without letting her see the figures. With each testimonio, the mothers affirmed Baudelia's anger as a rightful response to injustice. While school staff, reformers, and organizers condemned the mothers' anger as disruptive, Madres Unidas through testimonio affirmed anger as a healthy alternative to the self-blame and hurt that their school experiences would have otherwise inflicted; a necessary response to the politics of exclusion. As the Latina Feminist Group asserts, "We reclaim testimonio as a tool for Latinas to theorize oppression, resistance, and subjectivity" (2001:19).

Madres Unidas enabled Baudelia to persevere on the council in the face of much difficulty and, finally, supported her in resigning with dignity when the list of offenses became too much to tolerate. In one meeting, she read aloud the letter of resignation she had written for the principal and members of the council. The letter, itself a testimonio, listed her reasons for resigning and ended with the following clause: "I don't want to keep being a person who demands too much. I don't want you all to think I react this way because I am worn out, but on the contrary, because I like things to be clear, truthful, and just" (my translation from the Spanish). With her last point, Baudelia revealed her understanding that she was being viewed as a difficult person, "a person who demands too much" by the other members of the committee, and her rejection of this identity. The very act of writing the letter was a form of "counterstorytelling" (Solorzano and Yosso 2001; Villenas 2001), disrupting the dominant story she knew was likely to circulate about her resignation, and making public her own critique of the committee.

In sum, Madres Unidas created a community based on relations of wholeness, confianza, and respect that were denied the mothers at the school. Baudelia often said our weekly meetings were "like therapy." During one tape-recorded group reflection, she said, "For me, and I think for all of us, this group has helped, because the problems we have at school, we come [here] and unload them." At least, the group helped the mothers to "seguir adelante" (keep going) in the face of oppression. At most, it renewed their faith in their ability to create change. As Ofelia said of our weekly meetings, "I felt energized to keep working." 


\section{“Isn't This Research Over?"}

While university-based researchers engage in heated debate over whether and how to use research to promote change, for the mothers in Madres Unidas, change was the natural and expected outcome of their research. As they expressed repeatedly, the purpose of undertaking research on their children's school was to be able to implement change, both to correct what had gone wrong and to enable the school to fulfill its promise of change. Throughout our research, Madres Unidas demonstrated the seamless relationship between research and action that is at the heart of participatory research.

The concern about how to address the problems they identified emerged early in the research when Carmen observed that her first parent focus group had been "almost all complaints." In her reflection after the focus group she had written, "This really worries me, because we're going to bring the problems to light, but we can't resolve them right now." While the mothers were heartened by stories they heard indicating that the school was making a difference in the lives of some children, they were troubled by the continuing pattern of excluding parent voice, and they felt a personal responsibility to the parents who shared stories of pain and exclusion. As they debriefed particularly painful interviews in Ofelia's kitchen, they discussed the need to take action to heal the relationship between the school and these parents. They referred to the school's mission of being a "community school" and raised the question, What does it mean to be a community school? And when we talk about "community," who are we referring to? They decided to take these questions public to the staff at the end of the year.

Madres Unidas' research had two main products intended to change the relationship between staff and parents at the school: the first was a presentation to the school staff of their research process and findings, and the second was the creation of a parent center at the new small school. Through both products, Madres Unidas attempted to extend the practices of testimonio and confianza from the intimacy of Ofelia's kitchen into the school and to establish new forms of community in the school.

The presentation to the school staff involved several weeks of planning, in which we consulted with school coaches and OCCA organizers about how best to present the findings to a staff that had already shown itself hostile to critique. Although the coaches gave the mothers some useful advice, their responses to the mothers' findings also revealed their refusal to accept the mothers' analysis or their right to be agents of change in the school. During one planning meeting in which we were discussing how to involve the teachers in planning our next steps, the OCCA organizer had burst out, "What do you mean 'next steps'? Isn't this research over?" Her outburst reflected her belief that the Madres' research was a distraction from the "real" (legitimate) changework of organizing. It may also have reflected the belief that the mothers, apart from OCCA, were not capable of making change, a point I will return to later.

The school coaches gave the mothers other cautions that challenged the legitimacy of the Madres' research. First, they counseled the mothers to separate their personal experience from the "data" they obtained through interviews, and to remove their own experience from the presentation to the staff. Of course, the essence of the Madres Unidas' mujerista-inspired participatory research process was based on their own experience, which lent their research its power and authenticity. The coaches, in effect, were counseling the mothers to abandon the wholeness that had made their 
research process so transformative. The coaches emphasized that the mothers should help the school "move forward" and "not stay focused on the past." 7 This was another way of censoring the testimonies of pain and exclusion that the mothers had collected. In sum, the school's reform partners encouraged a sanitized presentation that would protect the staff (and themselves) from personal stress and public embarrassment.

The mothers were not discouraged by this advice. On the contrary, they embraced the coaching that was useful in their effort to gain legitimacy at the school, and they ignored the rest. Far from removing their personal experiences from the presentation, they opted for a presentation that highlighted their personal reactions to research findings as another form of testimonio. After each interview or research activity that they conducted during the year, the mothers had written a report including a summary or transcript of the activity, and their own reflections on what they had learned. These written reflections were powerful and eloquent testimonies about why the research mattered to them. At my suggestion, the mothers selected some of their reflections to read aloud to the teachers, thereby exposing their personal feelings of hurt and dismay (or, occasionally, joy and pride) alongside the "data" they collected. Importantly, they introduced their testimonies by explaining the confianza in Madres Unidas that had nurtured these reflections, and invited the staff to enter into their confianza. They shared with the staff about their process in Ofelia's kitchen, describing the food, the jokes, and the learning experiences they had shared as new researchers. They also described their data collection process and how they went about analyzing the data.

The opportunity to see parents in a new light was powerful for many teachers. As one teacher testified later, "I was just like, wow. They're so awesome. I've never had the opportunity to see this person in this light. Maybe she goes around in her personal life all the time like this, but I've never seen her this way, and that was really fun for me." The mothers' presentation revealed that parents could be and were very different outside of the school context, and had ways of being in a community that the school could learn from. Yvonne, a bilingual teacher, said, "I remember feeling after the presentation so incredibly appreciative of all the work that they did.... I just remember feeling, 'My God, that's the most incredible thing that's happened at the school this year!'"

In the end, the Madres Unidas approach was successful at gaining the teachers' and the principal's respect for their process and support for implementing change. Teachers testified that they were moved by the mothers' courage and honesty. As one teacher told me later in an interview:

I was really impressed with their honesty ... the honesty with which they presented what they had found. They touched on issues that people - staff in general-have been dancing around but not willing to confront ... and I was thinking, "I wish the staff would learn to do this the way this group of mothers has."

After the presentation, several staff spoke up to thank the mothers and congratulate them for their work. Perhaps most surprising to all of us, the principal thanked the mothers for their honesty and wondered how we could make it possible for more parents to engage in this research.

Only one person voiced disapproval in the presentation venue. It was the OCCA organizer, Martha. She argued that "the role of organizing didn't come out in the presentation," and that OCCA was not mentioned enough. She told the assembled 
group of staff and parents that none of them would be there if it were not for OCCA. "The danger of not recognizing the role of organizing," she said, "is that you need power to make change, and OCCA is a powerful organization." ${ }^{8}$ This was the clearest statement of her belief that parents were incapable of making change without OCCA. Indeed, OCCA's successes were based on the single-minded focus on building the organization's power. ${ }^{9}$ Now, voiced in the angry tone that it was, it communicated the message to the parents that "You're either with us or you're against us." As one of the mothers observed later, "That sounds like a threat."

The mothers later pondered why OCCA was so unwilling to recognize their research. Maelia suggested that perhaps it was "envidia" (envy). Certainly, it is important to recognize the role of organizing in bringing the small schools into being: many of the mothers had eagerly participated in this organizing and were aware of its victories. But at issue here was OCCA's unwillingness to accept any other means of achieving change-most notably that initiated by parents outside of OCCA's purview-or to acknowledge the need for other kinds of changes besides policy victories. Participatory research as practiced by Madres Unidas successfully engaged a group of low-income, limited-English-speaking immigrant mothers in examining serious reform issues at their children's school, and initiated a process of dialogue with teachers that forced teachers to reconsider the role of parents in the school. It created a new form of community for parents, and provided the context for parents to enact their vision of community at their children's school.

One of the most exciting outcomes of the research and the presentation to the staff was the creation of the parent center. Created with the support of three teachers in the fall after the parents' research, the parent center was intended to be a "second home" for parents in the school. As Ofelia explained, "The parent center was a dream of all of ours, of the group Madres Unidas . . . because we see that a parent center is a place where parents feel at home." In a grant proposal that they wrote collectively, Madres Unidas articulated the center's goals this way:

Our goal is for parents to be heard and feel part of the school, creating a family atmosphere where all families receive support ... since ... our purposes [are] to orient, assist, involve, and motivate the parents, so that they participate actively in the school, and for the Parent Center to be a second home for them. [emphasis added]

As a product of the Madres' research, the center was an expression of their goals for community and participation; a place to enact new ways of being parents in the school. One of the first activities the mothers organized for the parent center was a series of parent workshops to give parents the opportunity to speak on issues of importance to them. The workshops were a dramatic success and soon attracted more parents than the school's regular parent meetings. When I asked Maelia why this was so, she said:

[Parents] want to express what is happening with their child or with some member of the staff at the school and they can't [at the meetings]. They have to put their complaint in a box, and not say it in front of everyone. And I think that a parent should voice their opinion there, not stick it in a box without knowing if it will be read or thrown in the trash! $!^{10}$

In contrast, the parent workshops gave parents the opportunity to share very personal stories, and through this, build confianza. Maelia said: 
When they give testimonies, because a lot of mothers there have given their testimonies, they're giving us their confianza, and what is said in that group in the workshop doesn't leave the room. Because she is giving us her confianza by telling us what she's been through with her husband or her family, so it's a very personal atmosphere, and we're like a family. We're opening up, we're telling each other what we've been through, and we're trusting each other.

Through the parent center, Madres Unidas re-created a community based on confianza at the school. The center was also a place for the mothers to exercise new leadership roles in the school. Carmen and Maelia, two of the mothers who had been the most shy before joining Madres Unidas, organized the center's first parent workshop series, in collaboration with a community health agency. As Carmen testified:

I have gotten more courage, I'm not so afraid of people anymore! [laughs] Because before I could barely stand up from my seat to talk! ... I used to think I would never be able to do many things that I did [in this research]. I felt that I would never be able to do them. And I've learned to get out and interact with people I don't know, that for me was very hard. ${ }^{11}$

Carmen's story is one of many testimonies of change from Madres Unidas, the ripple effects of which will be felt for years to come. Her experience speaks to the need for multiple spaces that promote personal transformation, reminding us that for many women, this may be outside of formal education or organizing activities, and beyond the reach of policy. Feminist scholars remind us that resistance, for those who have been oppressed, is as much about personal healing and wholeness as it is about transforming structures of domination (hooks 1989, 1990; Latina Feminist Group 2001). We cannot hope to transform social structures without first transforming ourselves, without "remaking and reconstituting ourselves so that we can be radical" (hooks 1989:32). And there is evidence that the personal changes, once begun in the safety of home, generate more public forms of resistance.

While OCCA organizers claimed that Madres Unidas was alienating other parents, the mothers' expanded leadership roles in the school after our research ended suggest just the opposite: that they held considerable respect and moral authority among other parents. Near the end of our research, Ofelia was elected to the SSC, and the following year she was elected president (succeeding Baudelia, who had, after all, completed her term). Ofelia and Carmen were both selected to serve on the school's English Language Advisory Committee (ELAC), and both also served as parent representatives on a hiring committee to hire new teachers for the school. Maelia continued to be a volunteer coordinator for the parent center for the year following our research. In spite of the great frustrations they encountered in their first year as parent-researchers, the mothers did not lose faith in their ability to create change. As Ofelia said, reflecting on her role on the SSC, "I keep insisting, and thinking that we can make changes, and that they will listen to the parents. And my position on the committee is not to fill any requirement for the district, but to give voice to all the parents who are behind me."12

\section{Conclusion}

Researchers who hope to use their research for social change purposes face some difficult questions. In the first place, what kind of change? Change as defined by whom? What does it mean to align oneself with a political struggle, a social movement, 
or an organized group, when these entities are fractured with their own politics and inequalities? As feminist scholars have pointed out, even the most progressive political movements can and do reproduce patriarchy, racism, and other structures of social inequality (hooks 1989; Naples 2003). Unfortunately, to the extent that writing on activist research has focused on the tensions between academia and activism, between the university and "the community," we have neglected to examine the delicate dynamics within communities and activist movements. Communities are evolving, socially constructed collectivities fraught with politics and power relations of their own (Gregory 1998; Naples 2003). Ethnographers seeking to lend our work to the interests of disenfranchised groups need to be attentive to these power relations, and sensitive to the multiple ways our work might intersect with, reproduce, or disrupt them.

A Latina feminist or mujerista lens calls attention to the means of achieving change, and highlights the need for a research process that supports womanist ways of being in community, based on wholeness and confianza. Valuing wholeness means acknowledging the need for personal healing and for relationships that support our emotional, spiritual, and mental well-being as prerequisites for collective action. A mujerista perspective also presents a challenge to activist ethnography that uncritically engages only the most powerful actors in social change movements: community organizers, reform leaders, and district and school administrators. Had I continued as a single ethnographer, accountable primarily to movement leaders rather than to the Latina mothers who allowed me into their confianza, I would have missed the "hidden transcripts" of resistance (Scott 1990) that animated and sustained the mothers' engagement in the reform, and my ethnography might have unwittingly contributed to their silencing.

The lessons from Madres Unidas suggest two important limitations of policyoriented activist research. First, activist scholarship oriented exclusively to winning changes in the policy realm fails to illuminate the ways that social movements themselves reproduce inequality or the need for social actors to implement changes in their own lives and communities. While such research might contribute to important legal victories, it runs the risk of reproducing essentialized interpretations of social change movements whereby only academic experts and lawmakers are seen as knowing and doing what is best for disadvantaged communities. Second, to the extent that policyoriented activist research relies on a separation of roles between expert researcher and community members, it fails to illuminate the knowledge production of everyday people in the struggle for change.

Latina feminist scholarship moves the discussion of activist research forward by highlighting the knowledge production of Latina women in the home as an important resource for social change. However, for the most part such research only suggests how this might contribute to more public resistance or larger social movements (see Villenas 2001), and runs the risk of being dismissed by policy makers as purely "domestic," or, in the words of one male academic colleague, "empowering in an intimate sort of way." While feminist scholars have long been disputing the distinction between the "personal" and the "political," we still find ourselves in a context where it is vital for researchers to document the links between women's "private" resistance (and oppression) and public actions for social change. Participatory research from a Latina feminist perspective provides a way of building on Latinas' strategies for change and facilitating their movement into the "public" realm. It offers a research process that is at once humanizing and theoretically rigorous. While policy-oriented 
activist research depends on the researcher to sensitively represent and defend the interests of marginalized groups, mujerista participatory research illuminates and strengthens Latinas' own capacity for social critique and transformative resistance.

I have also shown, however, that this research is not without problems and risks of its own. I have tried to caution socially responsible researchers against the assumption that participatory research will be universally welcome within the social movements we aim to support. To the extent that our research promotes visible changes, we can expect resistance from institutional players who are accustomed to managing change themselves, and we might be surprised at their quickness to discredit our wellintentioned research. But this too reveals powerful insights about the barriers facing the most vulnerable actors in social change movements. Borrowing from critical race theorists, we might view our research among the least powerful actors as a form of "counterstorytelling" (Solorzano and Yosso 2001; Yosso 2006), disrupting the dominant story of reform and unearthing the untold stories of exclusion and resilience. In doing so, we can expect reproach from those who defend the dominant story-even for good and progressive reasons - and we must seek thoughtful ways of engaging them. The experience of Madres Unidas suggests that the way forward lies in illustrating the positive, transformative contribution of Latina womanist ways of being in community and their potential to revitalize school reform processes in the spirit of genuine democratic participation. As Madres Unidas repeatedly reminded school staff, "We're not here to criticize. We're here because we want something better for our children." Their courage in demanding new ways of being and becoming in their children's schools suggests that "something better" is within our reach, if we have the courage to listen and learn from the least powerful members of our communities.

In spite of the challenges I have highlighted, the purpose of this exploration is not to discourage scholars from socially engaged research, nor to promote one model of engaged research over another. It is, in the end, to counsel moral courage to those who insist on believing, as I do, that research should be about making life better for the people it touches. Nancy Scheper-Hughes (1995), in her seminal piece on activist anthropology, writes that her decision to become an activist-in Portuguese, a companheira - was not made by her but, rather, made for her by the women in the Brazilian shantytown who would not tolerate her research among them without enlisting her support in their struggles for justice. Likewise, the mothers in Madres Unidas had far less tolerance for indecision and inaction than I did, and they directed me to engage in ways I could never have conceived on my own. If we allow ourselves to be led into the thick of change by those most directly affected by the problems we study, we must be prepared to face the conflicts they face daily. Socially engaged research is, finally, an exercise in solidarity. The road is difficult, and we have only our own moral compass and our relationships with our compañeras to guide us.

Andrea Dyrness is an assistant professor of Educational Studies at Trinity College in Hartford, Connecticut (andrea.dyrness@trincoll.edu).

\section{Notes}

Acknowledgments. I would like to thank the five mothers in Madres Unidas for their collaboration, convivencia, and confianza. The James Irvine Foundation and the Center for Popular 
Education and Participatory Research at the University of California, Berkeley, provided financial and intellectual support for our research. I am also grateful to Kysa Nygreen; Michelle Fine; the Women, Gender, and Sexuality Studies Program writing group at Trinity College; and the anonymous reviewers at AEQ for their helpful and supportive comments on drafts of this article. A version of this article was presented as a paper at the 105th Annual Meeting of the American Anthropological Association, San Jose, California, November 15-19, 2006. Some of the data presented in this article was previously published in Dyrness 2007.

1. Reprinted in the December 2005 Anthropology and Education Quarterly (Emihovich 2005).

2. All quotes of the mothers in English are my translation from the Spanish.

3. For a succinct review of the roots of activist research in anthropology, see Speed 2006 and Hale 2006; in the field of education, see Nygreen 2006 and Foley and Valenzuela 2005.

4. In this article, I use the term Latina rather than Chicana, as used by Delgado Bernal (2006), because the women I worked with, who included immigrants from Central America, did not identify as Chicana.

5. The mothers later named the group Madres Unidas (Mothers United), placing themselves in a long history of mothers' organizing in Latin America and the United States.

6. Field notes, November 30, 2001.

7. Field notes, April 19, 2002.

8. Field notes, May 17, 2002. Martha is a pseudonym.

9. As Martha had told me previously, "We have to always be building our organization." For a detailed description of the community organizing model, see Richard Wood 2002, Mark Warren 2001, and Dennis Shirley 1997.

10. Taped interview, March 12, 2003.

11. Taped interview, June 4, 2002.

12. Taped interview, February 8, 2004.

\section{References Cited}

Benmayor, Rina

1991 Testimony, Action Research, and Empowerment: Puerto Rican Women and Popular Education. In Women's Words: The Feminist Practice of Oral History. Sherna Gluck and Daphne Patai, eds. Pp. 159-174. New York: Routledge.

Brown, Wendy.

1995 States of Injury: Power and Freedom in Late Modernity. Princeton: Princeton University Press.

Brown, Wendy, and Janet Halley

2002 Left Legalism/Left Critique. Durham, NC: Duke University Press.

Collins, Patricia

2000 Black Feminist Thought: Knowledge, Consciousness, and the Politics of Empowerment. 2nd edition. New York: Routledge.

Crozier, Gill

2001 Excluded Parents: The Deracialization of Parental Involvement. Race and Ethnicity in Education 4(4):329-341.

Delgado Bernal, Dolores

2006 Learning and Living Pedagogies of the Home. In Chicana/Latina Education in Everyday Life: Feminista Perspectives on Pedagogy and Epistemology. Dolores Delgado Bernal, C. Alejandra Elenes, Francisca Godinez, and Sofia Villenas, eds. Pp. 113-132. Albany: State University of New York Press.

Delgado Bernal, Dolores, C. Alejandra Elenes, Francisca Godinez, and Sofia Villenas, eds.

2006 Chicana/Latina Education in Everyday Life: Feminista Perspectives on Pedagogy and Epistemology. Albany: State University of New York Press.

Dyrness, Andrea

2004 Speaking Truth to Power: Immigrant Parents, Progressive Educators, and the Politics of Change in an Urban School. Ph.D. dissertation, School of Education, University of California, Berkeley.

2007 Confianza Is Where I Can Be Myself: Latina Mothers' Constructions of Community in Education Reform. Ethnography and Education 2(2):257-271. 
Emihovich, Catherine

2005 Fire and Ice: Activist Ethnography in the Culture of Power. Anthropology and Education Quarterly 36(4):305-314.

Fals-Borda, Orlando, and Mohammed A. Rahman

1991 Action and Knowledge: Breaking the Monopoly with Participatory Action-Research. New York: Apex.

Foley, Douglas, and Angela Valenzuela

2005 Critical Ethnography: The Politics of Collaboration. In The Sage Handbook of Qualitative Research. 3rd edition. Norman K. Denzin and Yvonna S. Lincoln, eds. Pp. 217-234. Thousand Oaks, CA: Sage.

González, Norma

2005 Reflections on the Field: Anthropology and Education-Past, Present, and Future. Paper presented at the 104th Annual Meeting of the American Anthropological Association, November 30-December 4, Washington, DC.

Gregory, Steven

1998 Black Corona: Race and the Politics of Place in an Urban Community. Princeton: Princeton University Press.

Hale, Charles

2006 Activist Research v. Cultural Critique: Indigenous Land Rights and the Contradictions of Politically Engaged Anthropology. Cultural Anthropology 21(1):96-120.

Hernández-Castillo, R. Aída

2006 Knowledge for What? Socially Committed Anthropology: Between Local Resistance and Global Powers. Paper presented at the Abriendo Brecha 3: Activist Scholarship Conference, Austin, Texas, February 16-18.

hooks, bell

1989 Talking Back: Thinking Feminist, Thinking Black. Boston: South End.

1990 Yearning: Race, Gender and Cultural Politics. Boston: South End.

Lareau, Annette, and Erin McNamara Horvat

1999 Moments of Social Inclusion and Exclusion: Race, Class, and Cultural Capital in Family-School Relationships. Sociology of Education 72(January):37-53.

Latina Feminist Group

2001 Telling to Live: Latina Feminist Testimonios. Durham, NC: Duke University Press.

Lipman, Pauline

2005 Educational Ethnography and the Politics of Globalization, War, and Resistance. Anthropology and Education Quarterly 36(4):315-328.

Maguire, Patricia

1987 Doing Participatory Research: A Feminist Approach. Amherst, MA: Center for International Education.

1993 Challenges, Contradictions, and Celebrations: Attempting Participatory Research as a Doctoral Student. In Voices of Change: Participatory Research in the United States and Canada. Peter Park, Mary Brydon-Miller, Budd Hall, and Ted Jackson, eds. Pp. 157-191. Westport, CT: Bergin and Garvey.

Murillo, Enrique G.

2002 How Does It Feel to Be a Problem?: "Disciplining" the Transnational Subject in the American South. In Education in the New Latino Diaspora: Policy and the Politics of Identity. Stanton Wortham, Enrique G. Murillo, and Edmund T. Hamman, eds. Pp. 215-240. Westport, CT: Ablex.

Naples, Nancy

2003 Feminism and Method: Ethnography, Discourse Analysis, and Activist Research. New York: Routledge.

Nygreen, Kysa

2006 Reproducing or Challenging Power in the Questions We Ask and the Methods We Use: A Framework for Activist Research in Urban Education. The Urban Review(38)1:126.

Park, Peter

1993 What Is Participatory Research?: A Theoretical and Methodological Perspective. In Voices of Change: Participatory Research in the United States and Canada. Peter Park, 
Mary Brydon-Miller, Budd Hall, and Ted Jackson, eds. Pp. 1-19. Westport, CT: Bergin and Garvey.

Scheper-Hughes, Nancy

1995 The Primacy of the Ethical: Propositions for a Militant Anthropology." Current Anthropology 36(3):409-440.

Scott, James

1990 Domination and the Arts of Resistance: Hidden Transcripts. New Haven, CT: Yale University Press.

Shirley, Dennis

1997 Community Organizing for Urban School Reform. Austin, TX: University of Texas Press.

Solorzano, Daniel, and Tara Yosso

2001 Critical Race and LatCrit Theory and Method: Counter-Storytelling. Qualitative Studies in Education 14(4):471-495.

Speed, Shannon

2006 At the Crossroads of Human Rights and Anthropology: Toward a Critically Engaged Activist Research. American Anthropologist 108(1):66-76.

Trinidad Galván, Ruth

2006 Campesina Epistemologies and Pedagogies of the Spirit: Examining Women's Sobrevivencia. In Chicana/Latina Education in Everyday Life: Feminista Perspectives on Pedagogy and Epistemology. Dolores Delgado Bernal, C. Alejandra Elenes, Francisca Godinez, and Sofia Villenas, eds. Pp. 161-179. Albany, NY: State University of New York Press.

Villenas, Sofia

2001 Latina Mothers and Small-Town Racisms: Creating Narratives of Dignity and Moral Education in North Carolina. Anthropology and Education Quarterly 32(1):3-28.

2005 Latina Literacies in Convivencia: Communal Spaces of Teaching and Learning. Anthropology and Education Quarterly 36(3):273-277.

Warren, Mark

2001 Dry Bones Rattling: Community Building to Revitalize American Democracy. Princeton, NJ: Princeton University Press.

Weis, Lois, and Michelle Fine

2000 Speed Bumps: A Student-Friendly Guide to Qualitative Research. New York: Teachers College Press.

Wood, Richard L.

2002 Faith in Action: Religion, Race, and Democratic Organizing in America. Chicago: University of Chicago Press.

Yosso, Tara J.

2006 Critical Race Counterstories along the Chicana/Chicano Educational Pipeline. New York: Routledge. 